\title{
Tubular Compression Fossils from the Ediacaran Nama Group, Namibia
}

\section{Citation}

Cohen, Phoebe A., Alexander Bradley, Andrew H. Knoll, John P. Grotzinger, Soren Jensen, John Abelson, Kevin Hand, Gordon Love, Joannah Metz, Nicola McLoughlin, Patrick Meister, Rebekah Shepard, Mike Tice, and Jonathan P. Wilson. 2009. Tubular compression fossils from the ediacaran nama group, namibia. Journal of Paleontology 83, no. 1: 110-122.

\section{Published Version}

http://dx.doi.org/10.1666/09-040R.1

\section{Permanent link}

http://nrs.harvard.edu/urn-3:HUL.InstRepos:3007641

\section{Terms of Use}

This article was downloaded from Harvard University's DASH repository, and is made available under the terms and conditions applicable to Open Access Policy Articles, as set forth at http:// nrs.harvard.edu/urn-3:HUL.InstRepos:dash.current.terms-of-use\#OAP

\section{Share Your Story}

The Harvard community has made this article openly available.

Please share how this access benefits you. Submit a story.

\section{Accessibility}


TUBULAR COMPRESSION FOSSILS FROM THE EDIACARAN NAMA GROUP, NAMIBIA

P.A. COHEN ${ }^{1}$, A. BRADLEY ${ }^{2}$, A.H. KNOLL ${ }^{2}$, J.P. GROTZINGER ${ }^{3}$, S. JENSEN ${ }^{4}$, J. ABELSON ${ }^{5}$, K.

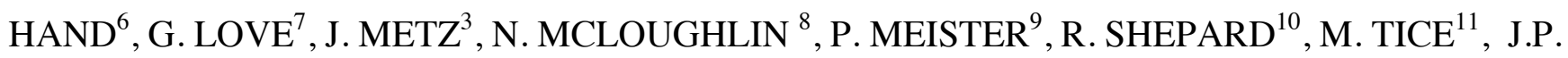
WILSON $^{1}$

${ }^{1}$ Department of Earth and Planetary Sciences, Harvard University, Cambridge MA 02138, <pacohen@fas.harvard.edu>,<jpwilson@fas.harvard.edu>; ${ }^{2}$ Department of Organismic and Evolutionary Biology, Harvard University, Cambridge MA 02138,<bradley@ fas.harvard.edu>, <aknoll@oeb.harvard.edu> ${ }^{3}$ Division of Geological and Planetary Sciences, California Institute of Technology, Pasadena $91125<$ grotz@gps.caltech.edu>, <joannah@its.caltech.edu>; ${ }^{4}$ Área de Paleontología, Facultad de Ciencias, Universidad de Extremadura, 06071 Badajoz Spain , <soren@unex.es>; ${ }^{5}$ Division of Biology, California Institute of Technology, 1200 E. California Blvd, Pasadena $91125<$ jabelson@biochem.ucsf.edu>; ${ }^{6}$ NASA Jet Propulsion Laboratory, California Institute of Technology, Pasadena $91109<$ khand@jpl.nasa.gov>; ${ }^{7}$ Department of Earth Sciences, University of California, Riverside $92521<$ glove@ucr.edu>; ${ }^{8}$ Centre for Geobiology, University of Bergen, P.O.BOX 7803, N-5020 Bergen, Norway < Nicola.Mcloughlin@geo.uib.no>; ${ }^{9}$ Max-Planck-

Institute for Marine Microbiology Celsiusstrasse 1,28359 Bremen, Germany <pmeister@mpibremen.de>; ${ }^{10}$ Department of Geology, University of California Davis, One Shields Avenue 956168605 <hepard@geology.ucdavis.edu>; ${ }^{11}$ Department of Geology and Geophysiscs, Texas A\&M, College Station, $77843<$ tice@ geo.tamu.edu>. 
ABSTRACT - Abundant tubular macrofossils occur in finely laminated siltstones and shales of the 548-542 Ma Schwarzrand Subgroup, Nama Group, Namibia. The Nama tubes occur in both the Vingerbreek and Feldschuhhorn members commonly in dense populations and always in fine-grained, lower shore-face lithologies deposited below fairweather wave base. The tubes are preserved mostly as compressed casts and molds that range in width from 0.6 to $2.1 \mathrm{~mm}$; apparently incomplete specimens reach lengths up to $10 \mathrm{~cm}$. All specimens show sinuous bending and occasional brittle fracture, indicating an original construction of strong but flexible organic matter. Feldschuhhorn specimens preserve fine longitudinal pleats or folds that record pliant organic walls, but the older Vingerbreek populations do not. Similarly, some specimens in the Feldschuhhorn Member display branching, while Vingerbreek tubes do not. The abundant Feldschuhhorn tubes are assigned to the widespread Ediacaran problematicum Vendotaenia antiqua; however, the distinctive Vingerbreek population remains in open nomenclature. The most abundant fossils in Nama rocks, these tubes resemble populations in Ediacaran successions from Russia, China, Spain, and elsewhere. Beyond their local importance, then, such tubes may turn out to be the most abundant record of Ediacaran life. 


\section{INTRODUCTION}

PALEONTOLOGISTS COMMONLY discuss Ediacaran life in terms of acritarchs and the distinctive Ediacara-type macrofossils so characteristic of much of the period. A number of deposits, however, indicate that a broader diversity of macroscopic organisms inhabited Ediacaran oceans. Calcified macrofossils associated with microbialites in Namibia, China, Oman, and North America preserve skeletal organisms not recorded by Ediacaran casts and molds (e.g., Germs, 1972; Grant, 1990; Grotzinger et al., 2000; Wood et al., 2002; Hua et al., 2007). Permineralized and compression fossils preserve a further diversity of unskeletonized macrofossils, with particularly well preserved and intensively studied assemblages in the Doushantuo Formation, China (e.g., Steiner, 1994; Yuan et al., 1999; Xiao and Knoll, 2000; Xiao et al., 2002, 2004; Tang et al., 2008).

Simple macroscopic tubes have long been found as compression fossils in basinal shales of Neoproterozoic age. These include simple cylindrical tubes, annulated cylindrical tubes, cylindrical tubes with transverse bands, cylindrical tubes with flanges, cylindrical tubes with transverse crosswalls, and cylindrical tubes with perforated cross-walls (Sokolov, 1968; Xiao and Dong 2006; Lui et al., 2008; Dong et al. 2008 and references therein). The simplest of these fossils are often grouped as vendotaenids and commonly cover bedding planes in Ediacaran shales of the Eastern European Platform and elsewhere (Gnilovskaya et al., 1988). Indeed, Droser and others (2005) have proposed that many structures reported as Ediacaran trace fossils are actually the casts and molds of tubular bodies, representing members of this greater diversity of macrofossils. Here we report two populations of tubular macrofossils, preserved largely as compressed casts and molds in fine-grained lithologies throughout the upper Ediacaran succession of the Nama Group, Namibia. Along with comparable populations in coeval rocks from Europe and Asia, these tubes preserve what may have been among 
the most abundant and widespread of all Ediacaran macroorganisms.

\section{GEOLOGIC SETTING}

The Nama Group of southern Namibia is interpreted as a late Neoproterozoic to Early Cambrian foreland basin fill that developed in northern and southern subbasins separated by the Osis arch (Figure 1; Gresse and Germs, 1993; Grotzinger and Miller, 2008). In the southern subbasin, Nama stratigraphy comprises six major marine ramp sequences containing mixed carbonate and siliciclastic lithologies (the Schwarzrand and Kuibus subgroups) overlain by alluvial and shallow marine siliciclastic rocks (the Cambrian Fish River Subgroup) (Saylor et al., 1995, 1998; Grotzinger, 2002; Grotzinger and Miller, 2008). Geochronological constraints on Nama deposition are provided by a number of $\mathrm{U} / \mathrm{Pb}$ zircon dates on intercalated ash beds. In the Schwarzrand Subgroup, the lower Spitskop Member of the southern subbasin has been dated at 545.1 $\pm 1 \mathrm{Ma}$, while a second ashbed in the upper part of the member reveals a 543 \pm 1 Ma age; in the Kuibis Subgroup, the lower Hoogland Member in the northern sub-basin has been dated at 548.8 $\pm 1 \mathrm{Ma}$ (Grotzinger et al., 1995) (Figure 1). These dates bracket the fossils described here.

All fossils described were recovered from the southern (Witputs) sub-basin. Fossils occur in both the lower and upper parts of the Schwarzrand Subgroup, in the Vingerbreek Member of the Nudaus Formation, and in the Feldschuhhorn Member of the overlying Urisis Formation. These shale members constitute outer shelf facies, formed during transgressive backstepping of coarser shelf sandstone units (Grotzinger and Miller, 2008).

The Vingerbreek Member consists of green mudstone with interbedded shale and sharp-based, thin- to medium-bedded, tabular-bedded sandstones which form 5-15 m thick, upward-shoaling parasequences (Grotzinger, 2002). Wave-rippled sandstones and siltstones are interbedded with these 
tabular-bedded sandstones and shales, or form separate units up to several meters thick of amalgamated rippled beds. The rippled beds are generally $2-10 \mathrm{~cm}$ thick and contain straight-crested, climbing, oscillatory and combined-flow ripples. Toward the top of some of the parasequences and near the top of the member, the tabular sandstones can be amalgamated into a stack of several beds without intervening shale. The tabular-bedded layers contain rare low-angle hummocky and trough cross-stratification and, in places, small- to medium-scale oscillation ripples that mark the top of beds. Gutter and flute casts and ball-and-pillow structures are present, indicating sporadic high-velocity flow events and rapid deposition. The ripple-marked units indicate shallow water depths above fairweather wave base; however, hummocky cross-beds in the tops of some amalgamated sandstone stacks record a greater water depth. Many of the fossils in the Vingerbreek Member occur in beds interpreted as the interval of maximum flooding of the shelf.

The Feldschuhhorn Member is a succession of green shales, siltstones, and sandstones deposited on Huns Formation limestones with a sharp contact. It represents flooding of the carbonate shelf and backstepping of shallow marine carbonate environments. Locally, pinnacle reefs formed during the accompanying increase in accommodation space, which culminated in shale deposition. It has not been possible to determine whether the onlapping shales and siltstones were deposited at the same time as the reefs at the top of the Huns, or subsequently (Saylor, 2003; Grotzinger and Miller, 2008). As with the Vingerbreek Member, the Feldshuhhorn shales occupy a position of maximum flooding on the shelf.

\section{MATERIALS AND METHODS}

Compressed tubular macrofossils occur in both the Vingerbreek and Feldschuhhorn members. In both horizons, the fossils occur in thinly laminated grey to dark grey siltstones interpreted as lower 
shore-face sediments deposited below fair-weather wave base during maximum flooding (Saylor, 2003; Grotzinger and Miller, 2008). A section through the fossiliferous upper Feldschuhhorn Member at the farm Sonntagsbrunn at $27^{\circ} 18^{\prime} 03^{\prime \prime} \mathrm{S}, 17^{\circ} 3918 \mathrm{E}$ (Figure 2.1) shows that fossils occur through $70 \mathrm{~m}$ of section, always in fine-grained, parallel-laminated rocks interbedded with fine-grained sandstones deposited during storms. Sandstone bedding surfaces rarely contain simple trace fossils; otherwise the tubes are the only macrofossils evident in outcrop. Vingerbreek fossils found at the Kliphoek farm at $26^{\circ} 45^{\prime} \mathrm{S} 16^{\circ} 33^{\prime}$ E occur sporadically through approximately $50 \mathrm{~m}$ of section in a similar environmental but slightly older stratigraphic context (Figure 2.2). In both localities, tubular macrofossils are abundant, occurring in high concentrations of randomly oriented individuals that cover bedding surfaces.

Morphological details of collected samples were analyzed using light microscopy and Scanning Electron Microscopy. Qualitative analysis of Vingerbreek and Feldschuhhorn samples was completed using a Zeiss Supra55 Field Emission Scanning Electron Microscope with an Energy Dispersive X-ray Spectrometer (EDAX). Spectra represent semi-quantitative chemical compositions of matrices and internal molds. Count peaks occur at voltages specific to individual elements based on the abundance of reflected X-rays produced by the interaction of minerals with the electron beam. We measured length and width of individual tubes on approximately $75 \%$ of all collected hand samples to generate size distributions.

Repository. - All specimens have been deposited in the Collections of the Geological Survey Museum, Windhoek, Namibia, under accession numbers F608 - F620.

\section{RESULTS}

Preserved Morphology. - Morphological detail is preserved primarily in compressed casts and 
molds of tube walls (Figures 3,4). The ribbon-like compressed tubes show little evidence of width variation along individual axes. Widths range from $0.6 \mathrm{~mm}$ to $2.1 \mathrm{~mm}$ (Figure 5) and commonly, but not always, show limited variation among individuals on single bedding surfaces. Vingerbreek and Feldschuhhorn populations both show a bimodal width distribution (Figure 5). Tubes reach lengths of up to $10 \mathrm{~cm}$, but, in life, were presumably longer, as no definitively complete fossils were found. Tubes typically have sharp terminations that are most easily interpreted as breaks rather than tips. A few of the Feldschuhhorn specimens show terminal swellings (Figure 3.5), but we are hesitant to interpret such structures, as they have the potential to be taphonomic artifacts. No clearly differentiated terminations were observed in hundreds of specimens from both localities. Unambiguous branching, both pseudomonopodial and dichotomous, occurs in Feldschuhhorn material (Figures $3.4,3.5$ ). In some cases, distinct lineations separate branches from the main tube wall (Figure 3.5). These are interpreted as either seamless branching flattened in two dimensions-i.e., where the main body of the tube is folded over the branching tube-or as a stem-like junction. No comparable pattern is evident in Vingerbreek specimens.

Vingerbreek and Feldschuhhorn populations similarly differ in terms of folding (Figure 3.2), which is evident in numerous Feldschuhhorn samples, but absent from Vingerbreek fossils (Figure 4). A number of Feldschuhhorn samples show distinct longitudinal striations (Figure 6.3), interpreted as taphonomic artifacts formed during compression of originally cylindrical bodies. Rare specimens from both horizons preserve faint transverse lineations (Bradley, 1998) (Figure 6.5). In Feldschuhhorn specimens, we also interpret these as taphonomic artifacts formed diagenetically due to their rarity and superficial quality (for comparison, see irregularly annulated specimens of the thin [approximately 40-140 mm wide] organic tube Rugosoopsis; Herman and Podkovyrov, 2007). Vingerbreek specimens have more robust annulations that may be original structures; they are also, however, rare. 
It is worth asking whether the organisms that produced these fossils were originally ribbon-like rather than tubular. Fossils in both assemblages are commonly preserved as partially compressed internal molds, and it is difficult to conceive of a mechanism by which originally flat, ribbon-like organisms would produce robust three-dimensional fossils. Moreover, we could not expect to see compression folds in fossils of originally two-dimensionalorganisms. Thus, we hypothesize that the original organisms had cylindrical bodies. Whether these bodies were solid, as in some metazoans, or hollow (fluid-filled), as in many algae, is more difficult to address. Regardless of their inner contents, however, the organisms preserved as Nama tubes had a differentiated external wall or sheath that preserved better than any internal tissues.

Taphonomy. - In hand specimens, the majority of the fossils stand out clearly because of their strong color contrast to the surrounding matrix; individuals are generally either rust-red or black. Based on EDAX peak locations and values, internal molds of Feldschuhhorn fossils consist primarily of iron-rich phyllosilicates, including chlorite, with a minor feldspar component occasionally present (Figure 7.1). Chlorites in tube fillings may well have originated via diagenesis of smectite group clays, especially in the presence of other iron minerals (Eberl et al., 1984). The surrounding matrix of Feldschuhhorn specimens is similarly clay-rich; infill material differs from matrix predominantly in its elevated $\mathrm{C}$ and $\mathrm{Fe}$ abundances (Figures 7.1, 7.2). SEM analysis of Feldschuhhorn specimens (Figure 6.4) shows a distinctive honeycombed pattern in the walls of the fossils not found in the surrounding matrix, consistent with the formation of pyrite crystals that were subsequently weathered out by oxidizing fluids. Early diagenetic pyrite formation is commonly associated with bacterial sulfate reduction in conjunction with locally high levels of reactive iron (Raiswell and Canfield, 1998), and both are expected where an influx of fine-grained siliciclastic sediment shields organicwalled organisms from oxygen (e.g., Zhu et al., 2005; Brock et al., 2006). Subsequent oxidation 
would account for the rust-red coloration and presumptive change in oxidation state of templating iron.

Vingerbreek tubes and matrix show rough similarity in infill and matrix composition with some significant differences (Figure 7.3). Relative to matrix, tube infillings are enriched in $\mathrm{Fe}$ and, notably, $\mathrm{Mg}$, but depleted in $\mathrm{K}, \mathrm{Al}$, and $\mathrm{Si}$. Elevated levels of iron in Vingerbreek samples could be due to similar processes at work in the Feldschuhhorn specimens. No evidence of evacuated pyrite crystals were observed under SEM, consistent with the tubes' darker and presumably unoxidized coloration. EDAX mapping of $\mathrm{Mg}$ shows covariation with Fe on a fine spatial scale, suggesting that Mg may be present in limited solid substitution within or absorption on Fe minerals. A handful of samples from the Vingerbreek are preserved as raised ridges, as opposed to compressions, a preservation style unique to this member (Figure 4.3, 8.3).

Similar macrofossils in other localities are commonly preserved as carbonaceous compressions, but that is not the case for most of the specimens considered here. Several features, however, indicate that the fossils were originally carbonaceous. Specimens show sinuous bends, indicating that living and recently dead specimens were flexible. Moreover, under SEM, multiple specimens from the Feldschuhhorn Member show distinct longitudinal striations interpreted as pleats or folds, again indicating a pliant wall composition (Figure 6.3). The organic content of most tube walls is low or non-existent; hydrofluoric acid maceration of Vingerbreek samples failed to reveal preserved organic matter. However, a single locality in the Feldschuhhorn Member contains tubes preserved by thin carbonaceous films, detected using low voltage EDAX (Figures 3.6, 7.2, 8.4).

The Nama tubes were buried by discrete pulses of sediment influx, each millimeter-scale lamina consigning the tubes beneath it to death and shielding their remains from oxidation. The high abundances and random orientation of tubes suggest that benthic populations were preserved more or 
less in place. A striking feature of the preserved populations on almost all bedding planes of both members is that the tubes tend to be of near-constant diameter on any single bedding plane - tube width varies between bedding planes, but rarely within them. Assuming width is a proxy for age, this suggests the preservation of "even age stands" on individual bedding surfaces, formed when episodic perturbations removed incumbent populations and opened space for local recolonization. One exception to this pattern is seen in the tube fossils preserved as carbonaceous films in the Feldschuhhorn Member (Figure 3.6). These fossils show a broader size distribution, but bedding planes are much less distinct at this locality, consistent with a greater degree of time averaging

In short, Vingerbreek and Feldschuhhorn siltstones and shales both contain abundant macrofossils of originally tubular organisms, but they preserve different populations. The Feldschuhhorn populations record occasionally branching tubes prone to decomposition by sulfate reducing bacteria, axial twisting during burial, and folding upon compression. The older Vingerbreek fossils do not branch, do not twist during deposition or fold during compression, and do not appear to have been equally accessible to sulfate-reducers (which could reflect environment as much as wall chemistry).

\section{DISCUSSION}

Traces versus Body Fossils. - Could the tubular fossils actually be trace fossils, or are they properly interpreted as body fossils? Feldschuhhorn tubes show several morphological features that immediately distinguish them from trace fossils, including the presence of folds and elevated levels of carbon (Figures 3.5, 7.2). In contrast, Vingerbreek material lacks obvious folds and does not show elevated levels of carbon. The Vingerbreek locality does include specimens preserved as raised ridges (Figure 4.3), which, if found in isolation, might well be interpreted as simple trace fossils. The 
differences in the composition of the Vingerbreek tubes and the surrounding matrix could be explained by changes caused by the passage of a burrower, including deposit of mucus and subsequent diagenesis.

The Vingerbreek population highlights a problem that can be particularly acute for Ediacaran strata: it is sometimes difficult, if not impossible, to distinguish a tubular macrofossil from a simple trace fossil with confidence. A number of lines of evidence indicate that, despite this difficulty, the Vingerbreek tubes bear greater similarity to known body fossils than to known trace fossils. Many specimens show sharp terminations formed by breakage, a feature that would not be found in a trace fossil. The general similarities in depositional setting and bedding plane distribution between Vingerbreek and Feldschuhhorn tubes also argue in favor of a common interpretation for the two populations. Further, the lack of evidence for cross-cutting relationships or bioturbation in these strata provides still further evidence in support of a body fossil interpretation. Thus, we interpret the Vingerbreek material as the direct remains of tubular organisms preserved through different pathways. Such a conclusion supports the hypothesis that some structures reported as Ediacaran trace fossils are actually the casts and molds of tubular bodies (Droser et al., 2005).

Phylogenetic Affinities and Global Distribution. - Morphologically similar compression fossils occur in other Ediacaran and early Cambrian successions, including localities in Spain, the East European Platform, and China (Table 1, Figure 9). The Vendian succession of the East European Platform is particularly well known for its carbonaceous tubes, of which Vendotaenia is the most widely known. Vendotaenia is described as having compressed tube- or ribbon-like thalli with rare branching and longitudinal fibrous textures; tube widths range from 0.25-3.5 mm (Gnilovskaya, 1971, 1983, 1990; Gnilovskaya et al., 1988) (Figures 9.1,9.2). Vendian Vendotaenia are preserved as carbonaceous films, especially in drill core samples, yet they provide close counterparts in terms of 
morphology and size to the Feldschuhhorn specimens. Thus, we assign the Feldschuhhorn fossils to Vendotaenia antiqua Gnilovskaya 1971. Germs et al. (1986) recovered fragmented macrofossils from drill core samples of Schwarzrand shales and assigned them to Vendotaenia sp. Our attribution is consistent with that determination, but made with much higher confidence.

Vendotaenia antiqua has commonly been interpreted as an alga, and Gnilovskaya (1983) interpreted morphological features as cell walls and oogonia. Vidal (1989), however, viewed these features as artifacts, reinterpreting $V$. antiqua as the preserved sheaths of sulfur-oxidizing bacteria such as Thioploca. Modern Thioploca are filamentous and have thin organic sheaths marked by longitudinal striations - both features are consistent with Nama and other Vendotaenia fossils. Moreover, the abundance of Thioploca at the oxic/anoxic interface is consistent with the hypothesis that sulfur-oxidizing bacteria radiated as rising oxygen levels increased the $\mathrm{P}_{\mathrm{O} 2}$ gradient at the sediment/water interface of Ediacaran oceans (see Canfield and Teske, 1996; Fike et al., 2006; Canfield et al., 2007). Such an interpretation, however, breaks down when one considers size: while Thioploca is large by bacterial standards, its sheaths have linear dimensions an order of magnitude lower than those of the Ediacaran fossils even when taking into consideration width expansion due to compression (Schultz et al., 1999). Moreover, Thioploca is not known to display branching. In the absence of additional character information, we leave $V$. antiqua among the problematica, but consider an algal interpretation reasonable.

Bearing in mind that the simple morphology of Ediacaran tubes creates challenges for taxonomy (see below), Vendotaenia populations have not only been reported from numerous localities within Redkino and Kotlin (<555 and >543 Ma: Martin et al., 2000) strata of the Eastern European Platform, but indeed, are globally distributed in Ediacaran shales (Hofmann, 1992). Macroscopic carbonaceous tubes occur in pre-Ediacaran successions (Hofmann, 1992), but rarely in the abundance 
observed in Ediacaran rocks.

As noted above, the Vingerbreek tube fossils differ in a number of salient characteristics from Feldschuhhorn V.antiqua populations. Consistent with such morphological diversity within the Nama, a global diversity of tubular macrofossils is preserved in other Ediacaran and Lower Cambrian shales. On the East European Platform, for example, Gnilovskaya (1988) recognized nine vendotaenid genera, differentiated by size, branching pattern and/or surface texture. Several of these could be synonymous, but clearly, more than one type of organism contributed to the tubular compressions in Ediacaran rocks from European Russia. Among the proposed Russian taxa, Tyrosotaenia podolica Gnilovskaya 1971 is of particular interest (Figure 9.3). Gnilovskaya (1971) described Tyrasotaenia as unbranched ribbons with smooth surfaces, occasionally folded, and displaying both twisting and bending. Type populations of $T$. podolica differ from Vingerbreek populations most conspicuously in their smaller size (Table 1) and propensity to twist and bend sharply.

The Nama tubes also bear comparison to Sinocylindrica yunnanensis, smooth carbonaceous ribbons found in the Ediacaran Doushantuo Formation and Lower Cambrian Chengjiang Formation of China (Xiao et al., 2002). Tubes of $S$. yunnanensis are $0.2-0.35 \mathrm{~mm}$ wide and inferred to be flexible. Some specimens show signs of folding, but no evidence of branching (Xiao et al., 2002). S. yunnanensis has been compared to both cyanobacterial sheaths and laminarian brown algae such as Chorda (Hou et al., 2004). Other carbonaceous tubes from the Doushantuo formation, the Chengjiang Formation, and coeval material from Eastern European cores bear resemblance to the Nama tubes as well, especially longitudinally striated material from the Perevalok Formation of the Central Urals (Grazhdankin et al., 2007; Xiao et al., 2002) and unnamed Vendotaenia-like carbonaceous tubes from the Chengjiang Formation (M. Moczydlowska-Vidal, unpublished data). 
Another comparison worth noting is with the basal Cambrian carbonaceous tube Sabellidites (Sokolov, 1972; Korkutis, 1981). Sabellidites and the Vingerbreek fossils are similar: both are long, thin, and unbranched compressed fossils of hypothesized originally cylindrical bodies. The Vingerbreek tubes differ from Sabellidites in that some populations of the latter form interwoven filaments (Ivantsov, 1990; Moczydlowska, 2003), of which no evidence is found in Nama fossils. Sabelliditids also commonly show distinct transverse laminations that impress upon the encompassing matrix (Korkutis, 1981). Specimens in previously examined Vingerbreek material include individuals with faint transverse annulations (Bradley, 1998), but their occurrence is neither as pronounced nor as widespread within the population as the annulations in Sabellidites. We are hesitant to affix generic and specific names to the Vingerbreek population, preferring to leave it in open nomenclature until global restudy of Ediacaran tubular fossils provides a clear taxonomic framework for these simple but abundant fossils.

While the Nama localities preserve a wider range of morphologies and preservation modes than most previously studied areas, diverse tubular fossils recently reported from the latest Ediacaranbasal Cambrian of central Spain are similarly diverse. Work in progress suggests the presence of both vendotaenids and sabelliditids, with examples of the latter only occurring in the upper part of the series (Vidal et al., 1994; Contreras Sanchez et al., 2006; Jensen et al., 2007). Tubular fossils occur in great abundance in dark mudstones and fine sandstones and are the only macrofossils present. The fossils reflect various modes of preservation, including carbonaceous films and phyllosilicate casts, as well as sediment-filled ridges and grooves (Contreras Sanchez et al., 2007; Jensen et al., 2007). In the latter mode of preservation there is a strong similarity to simple trace fossils and it is possible that some of the trace fossils reported from these strata are instead three-dimensionally preserved tubular organisms (Jensen et al., 2005b, 2006, 2007). 
Modern Analogs. - Tubular and ribbon-like fossils found in the Nama formation and other localities may include large prokaryotes, but most probably represent algae or metazoa. No perfect modern analogs exist, but various extant algae exhibit morphologies consistent with both groups of Nama tubes. Within the brown algae, for example, Chorda filum bears the most obvious morphological similarity to the unbranched Vingerbreek fossils (Graham and Wilcox 1999). Chorda occurs in shallow marine environments and consists of long, narrow, flexible fronds that attach to the sea floor by means of a holdfast, with unbranched fronds reaching two to three meters in length. The walls of brown algae contain high amounts of the polysaccharide alginate (Chizhov et al., 1999), a viscous gum that could potentially allow for preservation under conditions of rapid burial. However, the Laminariales, the phaeophyte order to which Chorda belongs, are thought to have diverged only in the Cenozoic, making direct comparison with Ediacaran fossils difficult (Graham and Wilcox, 1999). Another morphological analog is provided by the green alga Enteromorpha, a cylindrical variant of the Chlorophyte Ulva (Figure 10), although such algae probably have a relatively low preservation potential. Within the red algae, intertidal Nemalion bears the strongest morphological resemblance to the Feldschuhhorn tubes (Xiao et al., 2002), with long, occasionally branched fronds. Comparison with macroalgal analogs appears fruitful when taking into consideration the presence of branching in Feldschuhhorn specimens. In the absence of preserved reproductive structures or other morphological details, however, it would be challenging to differentiate cylindrical fossils of macroscopic green, red, or brown algae.

The Vingerbreek fossils preserved with apparent faint transverse annulations are consistent with growth along an open apical margin, a kind of growth found only in metazoans. Broad comparisons can be drawn between the Vingerbreek tubes and structures found in a handful of extant metazoan groups, including pogonophoran worm tubes and scyphozoan polyp sheaths (Babcock et al., 
2005). Scyphozoan tubes are chitinous and elastic, whereas pogonophoran tubes consist of a proteinchitin complex; both have the potential for preservation as strong but flexible compressions in the fossil record. Sabelliditid fossils have been interpreted as scyphozoan tubes by some workers, pogonophorans by others (Sokolov, 1967; Hofmann, 1994). However, most such organisms show variation in width along their lengths and display external morphological features not found in any of the Nama compression fossils. Additionally, the lack of annulations in dozens of specimens examined from each locality and the faint and superficial quality of those observed emphasizes the possibility that those seen in isolated specimens could be preservational artifacts.

Both algal and metazoan interpretations of the Nama tubes are consistent with current knowledge of the timing of animal and macroalgal evolution in Ediacaran Period (Narbonne, 2005; Xiao et al., 2004; Knoll et al., 2006). We favor an algal interpretation for the Feldschuhhorn population of $V$. antiqua based on their morphology, while the Vingerbreek tubes remain more enigmatic. Regardless of taxonomic affinity, the global distribution and sudden appearance of such tubes signal a widespread expansion of macroscopic organisms in basinal environments of Ediacaran oceans.

Timing of Appearance of Tubular Macrofossils. - While carbonaceous macrofossils are known throughout the Proterozoic record, high-density populations of macroscopic tubes such as those preserved in Nama shales have not been reported from pre-Ediacaran successions; nor are they much in evidence after the Cambrian Period. In the Vendian succession of the East European Platform, compressed tubes occur predominantly in the Kotlin horizon, above the regional record of conventional Ediacaran fossils (Gnilovskaya et al., 1988). Whether this represents evolutionary sequence or ecological circumstance is uncertain. Unlike the underlying Redkino succession, Kotlin beds are predominantly carbonaceous shales deposited in off-shore environments. Vendotaenids do 
occur regionally in the Redkino succession wherever off-shore shales are preserved. In the Nama Group, tubular macrofossils, conventional Ediacaran remains, and calcified macrofossils are interstratified, segregating along paleoenvironmental lines. Earlier Ediacaran history is less well represented by sedimentary rocks than the later history of this period; nonetheless, we know of no well-documented occurrences of densely packed vendotaenid or other tube fossils in rocks older than approximately 555 million years.

We interpret the apparent time restriction of densely packed tube fossils to reflect the combined effects of evolutionary innovation and taphonomic processes. Closure of the taphonomic window for dense tube populations reflects the advent of significant bioturbation, especially in deep shore-face environments (Orr et al., 2003): the distinct, finely laminated bedding planes on which Nama tubes occur are a rarity in productive oxic Phanerozoic shelf areas (Jensen et al., 2005a). Moreover, the Cambro-Ordovician expansion of diverse macroalgae and invertebrate benthos across platform and shelf environments concomitantly reduced the seafloor space available for colonization by tube organisms.

What, then, opened the window for tube fossilization? There is no reason to believe that taphonomy governed this opening, as macroscopic compressions are commonly preserved in Proterozoic shales (Hofmann, 1992; Butterfield, 2003). Both macroscopic and demonstrably multicellular eukaryotes first appeared well before the Ediacaran Period (Hofmann, 1992; Butterfield, 2000), but the delayed expansion of diverse, macroscopic algae and macroscopic animals (Xiao et al., 2004; Narbonne, 2005) occurred only in concert with rising oxygen tensions in the Ediacaran atmosphere and oceans (Fike et al., 2006; Canfield et al., 2007, 2008; McFadden et al., 2008; Scott et al., 2008; Shen et al., 2008). In this respect, it is not the oxygen content of the surface ocean that is of concern as much as oxygen levels in and above the oxygen minimum zone. Increasing geochemical 
evidence suggests that subsurface water masses were commonly anoxic until 580-560 million years ago, with episodic recurrence of oxygen deprivation even later (Fike et al., 2006; Canfield et al., 2007, 2008; McFadden et al., 2008; Scott et al., 2008; Shen et al., 2008). To the extent that Ediacaran tube organisms were multicellular eukaryotes, colonization of basinal substrates would only have been possible as oxygen partial pressures increased. At the same time, Late Neoproterozoic oxygenation dramatically changed the nitrogen cycle, enabling nitrate abundances to build up throughout the oceans. This circumstance would also have favored the expansion of eukaryotic photoautotrophs across continental shelves and platforms (Anbar and Knoll, 2002; Knoll et al., 2007).

The establishment of a strong oxygen gradient between seawater and subsurface sediments would also have facilitated the expansion of chemoautotrophic prokaryotes that exploit the oxic/anoxic interface (Canfield and Teske, 1995) until bioturbation modified that gradient. Thus, the global expansion of tube fossil populations in Ediacaran oceans is consistent with our understanding of Neoproterozoic environments and evolution.

Ecological Significance. - While they lack the charismatic features of the contemporaneous Ediacaran fauna, tubular fossils such as those from the Nama Group may well be the most common and abundant macrofossils in the Ediacaran Period. They have the potential to account for a large proportion of terminal Ediacaran biomass, opening a new page in carbon cycling. In modern marine systems, primary production rates in macroalgal communities range from 1.75 to $14.6 \mathrm{~kg} / \mathrm{m}^{2} / \mathrm{yr}$ (Graham and Wilcox, 1999), rates equal to or greater than those in the most productive terrestrial plant communities.

\section{CONCLUSIONS}

The morphological simplicity of the Nama tube fossils and a general lack of distinguishing 
features make definitive taxonomic categorization difficult. Whether algal or animal, documentation of widespread tubular macrofossils supports the hypothesis put forth by Droser et al. (2005) that many of the bedding plane features originally interpreted as simple trace fossils in Ediacaran successions in fact record body fossils of cylindrical or ribbon-like organisms. What we lose in the ichnofossil diversity of Ediacaran rocks, we make up in the abundance and taxonomic richness of body fossils. The consistent presence of tubular compression fossils in tens of meters of section in the Nama Group and in numerous other globally distributed localities indicates that these organisms were a significant component of Ediacaran biomass and may prove to be the most abundant macrofossils in the Ediacaran system as a whole. Estimates of terminal Neoproterozoic organic carbon cycling and reconstructions of ecosystem function must take into consideration the role of such tubular macroorganisms in global marine environments. A satisfying functional and biogeochemical understanding of these fossils, however, will come only with a more comprehensive examination of the distribution, diversity, abundance, and phylogenetic relationships of tubular macrofossils in late Neoproterozoic rocks.

\section{ACKNOWLEDGMENTS}

This project was supported by a gift from the Agouron Institute (to AHK and JPG) to support advanced field research and education in historical geobiology. All but one of the authors participated in the field mapping that underpins the research reported here. We thank G. Narbonne and S. Xiao for helpful reviews, M. Moczydlowska-Vidal and M.B. Gnilovskaya for access to comparative materials and B. Gaines, P. Orr, N. Tosca, and D. Johnston for helpful discussion. This work was performed in part at the Center for Nanoscale Systems (CNS), a member of the National Nanotechnology Infrastructure Network (NNIN), which is supported by the National Science Foundation under NSF 
award no. ECS-0335765.

\section{REFERENCES}

ANBAR, A. D., AND A.H. KNOLL. 2002. Proterozoic ocean chemistry and evolution: a bioinorganic bridge? Science, 297:1137-1142.

BABCOCK, L. E., GRUNOW, A. M., SADOWSKI, G. R., AND S.A. LESLIE. 2005. Corumbella, an Ediacaran-grade organism from the late Neoproterozoic of Brazil. Palaeogeography, Palaeogeography, Palaeoecology, 220:7-18.

BRADLEY, A.S. 1998. A New Vendian Body Fossil from the Nama Group of Namibia: Evolutionary and Biostratigraphic Implications. Unpublished B.A. Thesis, Harvard College, 60 p.

BROCK, F., R.J. PARKES, AND D.E.G. BRIGGS. 2006. Experimental pyrite formation associated with decay of plant material. Palaios, 21:499-506.

BUTTERFIELD, N. J. 2000. Bangiomorpha pubescens n. gen., n. sp.: implications for the evolution of sex, multicellularity, and the Mesoproterozoic/Neoproterozoic radiation of eukaryotes. Paleobiology, 26:386-404.

BUTTERFIELD, N. J. 2003. Exceptional fossil preservation and the Cambrian explosion. Integrative and Comparative Biology, 43:166-177.

CANFIELD, D. E., AND A. TESKE. 1996. Late Proterozoic rise in atmospheric oxygen concentration inferred from phylogenetic and sulphur-isotope studies. Nature, 382:127-132. 
CANFIELD, D. E., S.W. POULTON, AND G.M. NARBONNE. 2007. Late-Neoproterozoic deepocean oxygenation and the rise of animal life. Science, 315:92-95.

CANFIELD, D. E., S.W. POULTON, A.H. KNOLL, G.M. NARBONNE, G. ROSS, T. GOLDBERG, AND H. STRAUSS. 2008. Ferruginous conditions dominated later Neoproterozoic deep water chemistry. Science 321: 949-952.

CHIZHOV, A. O., DELL, A., MORRIS, H. R., HASLAM, S. M., MCDOWELL, R. A., AND A.S. SHASHKOV. 1999. A study of fucoidan from the brown seaweed Chorda filum. Carbohydrate Research, $320: 108-119$.

CONTRERAS SÁNCHEZ, M., M. MARTÍ MUS, AND S.R. JENSEN. 2007. Filamentous carbonaceous compressions from the terminal Ediacaran-Cambrian of central Spain. Palaeontological Association Newsletter, 66, p. 68.

CONTRERAS SÁNCHEZ, M.M., JENSEN, S.R., AND T. PALACIOS. 2006. Sabelidítidos y vendoténidos del Anticlinal de Ibor (Zona Centroibérica). XXII Jornadas de la Sociedad Española de Paleontología. Libro de Resúmenes, 101-103.

DONG. L., S. XIAO, B. SHEN, X. YUAN, X. YAN, AND Y. PENG. 2008. Restudy of the worm-like carbonaceous compression fossils Protoarenicola, Pararenicola, and Sinosabellidites from early Neoproterozoic successions in North China. Palaeogeography, Palaeoclimatology, Palaeoecology, 258:138-161. 
DROSER, M. L., J.G. GEHLING, AND S.R. JENSEN. 2005. Ediacaran trace fossils: true and false. In D. E. Briggs (ed.), Evolving Form and Function: Fossils and Development. Peabody Museum of Natural History, New Haven, pp 125-138.

EBERL, D. D. 1984. Clay mineral formation and transformation in rocks and soils; clay minerals; their structure, behaviour and use. Philosophical Transactions of the Royal Society, London, Series A: Mathematical and Physical Sciences, 311:241-257.

FIKE, D. A., J.P. GROTZINGER, L.M. PRATT, AND R.E. SUMMONS. 2006. Oxidation of the Ediacaran ocean. Nature, 444:744-747.

GERMS, G. J. B. 1972. New shelly fossils from Nama group, South West Africa. American Journal of Science, 272:752-761.

GERMS, G. J. B., A.H. KNOLL, AND G. VIDAL. 1986. Latest Proterozoic microfossils from the Nama Group, Namibia (South West Africa). Precambrian Research, 32:45-62.

GNILOVSKAYA, M. B. 1971. The oldest aquatic plants of the Vendian of the Russian Platform (late Precambrian). Paleontological Journal, 5:372-378.

GNILOVSKAYA, M. B. 1983. Vendotaenides. In A. Urbanek and A.Yu. Rozanov (eds.), Upper Precambrian and Cambrian Paleontology of the East European Platform. Publishing House Wydawnictwa Geologiczne: Warsaw, Poland pp. 46-56. 
GNILOVSKAYA, M. B. 1990. Vendotaenids; Vendian metaphytes. In B. S. Sokolov, \& A. B. Iwanowski (eds.), The Vendian System. Vol. 1 Paleontology. Springer-Verlag: New York,NY, pp. 138-147.

GNILOVSKAYA, M.B., A.A. ISTCHENKO, CH..M. KOLSHNIKOV, L.V. KORENCHUK, AND A.P. UDALSTOV. 1988. Vendotaenids of the East European Platform. Leningrad: Nauka, 143 pp.

GRAHAM, L. E., AND L.E. WILCOX. 1999. Algae. Upper Saddler River, NJ: Prentice Hall, 604 pp.

GRANT, S. W. F. 1990. Shell structure and distribution of Cloudina, a potential index fossil for the terminal Proterozoic; Proterozoic evolution and environments. American Journal of Science, 290-A:261-294.

GRAZHDANKIN, D., AND K. NAGOVITSIN. 2007. Late Vendian Miaohe-type ecological assemblage of the East European Platform. Doklady Earth Sciences, 417:1183-1187.

GRESSE, P. G., AND G.J.B. GERMS. 1993. The Nama foreland basin; sedimentation, major unconformity bounded sequences and multisided active margin advance. Precambrian Research, 63:247-272.

GROTZINGER, J. P. 2002. Stratigraphy, facies, and paleoenvironmental setting of a terminal Proterozoic carbonate ramp, Nama Group (ca. 550-543 Ma), Namibia: Johannesburg, South Africa, 16th International Sedimentological Congress, Field Guide, 71 p. 
GROTZINGER, J. P., S.A. BOWRING, B.Z. SAYLOR, AND A.J. KAUFMAN. 1995.

Biostratigraphic and geochronologic constraints on early animal evolution. Science, 270:598604.

GROTZINGER, J. P., W.A. WATTERS, AND A.H. KNOLL. 2000. Calcified metazoans in thrombolite-stromatolite reefs of the terminal Proterozoic Nama Group, Namibia. Paleobiology, 26:334-359.

GROTZINGER, J.P., AND R. McG. MILLER. 2008. Nama Group. In Miller, R. McG. (ed.) The Geology of Namibia, Vol. 2, Geological Survey of Namibia, p. 13.229 - 13.272.

HERMAN, T. N., AND V.N. PODKOVYROV. 2005. On the animal nature of the late Riphean Rugosoopsis. Paleontological Journal, 39:582-589.

HOFMANN, H. J. 1992. Proterozoic and selected Cambrian mega-scopic dubiofossils and pseudofossils. In J. W. Schopf and C. Klein (eds.), The Proterozoic biosphere: A multidisciplinary study. Cambridge University Press, Cambridge, pp. 1035-1053.

HOFMANN, H.J. 1994. Proterozoic carbonaceous compressions ("metaphytes" and "worms"). In S. Bengston (ed.), Early Life on Earth. Columbia University Press, New York, pp. 342-357.

HOU, X.-G., R.J. ALDRIDGE, J. BERGSTROM, D.L. SIVETER, D.J. SIVETER, AND X.-H. FENG. 2004. The Cambrian Fossils of Chengjiang, China: The Flowering of Early Animal Life. Blackwell Publishing, Malden Massachusetts, 233 p.

HUA, H., Z. CHEN, AND X. YUAN. 2007. The advent of mineralized skeletons in Neoproterozoic metazoa; new fossil evidence from the Gaojiashan fauna. Geological Journal, 42:263-279. 
IVANTSOV, A.Y. 1990. New data on the ultrastructure of sabellidites (Pogonophora?). Paleontologicheskii Zhurnal, 24: 125-128.

JENSEN, S., M.L. DROSER, AND J.G. GEHLING. 2005a. Trace fossil preservation and the early evolution of animals. Palaeogeography, Palaeoclimatology, Palaeocology, 220:19-29.

JENSEN, S., T. PALACIOS, AND M. MARTI MUS. 2005b. Megascopic filamentous organisms preserved as grooves and ridges in Ediacaran siliciclastics. Paleobios, 25, Suppl. to $\mathrm{nr}$ 2, 65-66.

JENSEN, S., M.L. DROSER, AND J.G. GEHLING. 2006. A critical look at the Ediacaran trace fossil record. In Xiao, S. \& Kaufman, A.J. (eds.) Neoproterozoic Geobiology and Paleobiology, p. 115-157. Springer.

JENSEN, S., T. PALACIOS, AND M. MARTI MUS. 2007. A brief review of the fossil record of the Ediacaran - Cambrian transition in the area of Montes de Toledo - Guadalupe, Spain. In P. Vickers-Rich (ed). The rise and fall of the Ediacaran biota. Geological Society of London Special Publication 286, 223-235.

KNOLL, A. H., E.J. JAVAUX, D. HEWITT, AND P. COHEN. 2006. Eukaryotic organisms in Proterozoic oceans, Philosophical Transactions of the Royal Society, London. Biological Sciences, 361:1023-1038. 
KNOLL, A.H., R.E. SUMMONS, J. WALDBAUER, AND J. ZUMBERGE. 2007. The geological succession of primary producers in the oceans. In P. Falkowski and A.H. Knoll (eds.), The Evolution of Primary Producers in the Sea. Burlington, Elsevier, pp. 133-163.

KORKUTIS, V. 1981. Late Precambrian and Early Cambrian in the East European Platform. Precambrian Research, 15:75-94.

LIU, P., S. XIAO, C. YIN, C. ZHOU, L. GAO, AND F. TANG. 2008. Systematic description and phylogenetic affinity of tubular microfossils from the Ediacaran Doushantuo Formation at Weng'an, South China. Palaeontology 51: 339-366.

MARTIN, M. W., D. V. GRAZHDANKIN, S.A. BOWRING, D.A.D. EVANS, M.A..FEDONKIN, AND J.L. KIRSCHVINK. 2000. Age of Neoproterozoic bilaterian body and trace fossils, White Sea, Russia; implications for metazoan evolution. Science, 288:841-845.

MCFADDEN K.A., J. HUANG, X. CHU, G. JIANG. A.J. KAUFMAN, C. ZHOU, X. YUAN, AND S. XIAO. 2008. Pulsed oxidation and biological evolution in the Ediacaran Doushantuo Formation. Proceedings of the National Academy of Sciences, USA 105: 3197-3202.

MOCZYDLOWKSA, M. 2003. Earliest Cambrian putative bacterial nanofossils. Memoirs of the Association of Australasian Palaeontologists, 29, 1-11.

NARBONNE, G.M. 2005. The Ediacaran Biota: Neoproterozoic origin of animals and their Ecosystems. Annual Review of Earth and Planetary Sciences, 33:412-442.

ORR, P. J., M.J. BENTON, AND D.E.G. BRIGGS. 2003. Post-Cambrian closure of the deep-water slope-basin taphonomic window. Geology, 31:769-772. 
RAISWELL, R., AND D.E. CANFIELD. 1998. Sources of iron for pyrite formation in marine Sediments. American Journal of Science, 298:219-245.

SAYLOR, B. Z. 2003. Sequence stratigraphy and carbonate-siliciclastic mixing in a terminal Proterozoic foreland basin, Urusis Formation, Nama Group, Namibia. Journal of Sedimentary Research, 73:264-279.

SAYLOR, B. Z., J.P. GROTZINGER, AND G.J.B. GERMS. 1995. Sequence stratigraphy and sedimentology of the Neoproterozoic Kuibis and Schwarzrand subgroups (Nama Group), Southwestern Namibia; Neoproterozoic stratigraphy and earth history. Precambrian Research, 73:153-171.

SAYLOR, B. Z., A.J. KAUFMAN, J.P. GROTZINGER, AND F. URBAN. 1998. A composite reference section for terminal Proterozoic strata of southern Namibia. Journal of Sedimentary Research, 68:1223-1235.

SCHULZ, H. N., T. BRINKHOFF, T.G. FERDELMAN, M.H. MARINÉ, A. TESKE, AND B.B. JØRGENSEN. 1999. Dense populations of a giant sulfur bacterium in Namibian shelf sediments. Science, 284:493-495.

SCOTT, C., T. W. LYONS, A. BEKKER, Y. SHEN, S. W. POULTON, X. CHU, AND A. D. ANBAR. 2008. Tracing the stepwise oxygenation of the Proterozoic ocean. Nature, 452: 456458. 
SHEN Y., T. ZHANG, AND P.F. HOFFMAN. 2008. On the coevolution of Ediacaran oceans and animals. Proceedings of the National Academy of Sciences, 105: 7376-7381.

SOKOLOV, B.S. 1967. The oldest Pogonophora. Doklady Akademia Nauk SSSR 177(1): 201-204.

SOKOLOV, B.S. 1968. Vendian and Early Cambrian Sabelliditida (Pogonophora) of the USSR. Proceedings, 23rd International Geological Congress, Prague, pp. 79-96.

SOKOLOV, B.S. 1972. Vendian and Early Cambrian Sabellidita (Pogonophora) of the USSR. Proceedings of the 23rd International Geological Congress, Proceedings of the International Palaeontological Union, 79-86.

STEINER, M. 1994. Die neoproterozoischen Megaalgen Sudchinas. Berliners Geowissenschaftliche Abhandlungen, Reihe E, Band 15, 146 pp.

TANG, F., C. YIN, S. BENGSTON, P. LIU, Z. WANG, AND L. GAO. 2008. Octoradiate spiral organisms in the Ediacaran of South China. Acta Geological Sinica, 82:27-34.

VIDAL, G. 1989. Are late Proterozoic carbonaceous megafossils metaphytic algae or bacteria? Lethaia 22:375-379.

WOOD, R. A., J.P. GROTZINGER, AND J.A.D. DICKSON. 2002. Proterozoic modular biomineralized metazoan from the Nama Group, Namibia. Science, 296:2383-2386.

XIAO, S. 2004. New multicellular algal fossils and acritarchs in Doushantuo chert nodules (Neoproterozoic, Yangtze Gorges, South China). Journal of Paleontology, 78:393-401. 
XIAO, S., AND A.H. KNOLL. 2000. Phosphatized animal embryos from the Neoproterozoic Doushantuo formation at Weng'an, Guizhou, South China. Journal of Paleontology, 74:767788.

XIAO, S. AND L. DONG. 2006. On the morphological and ecological history of Proterozoic macroalgae, In S. Xiao and A.J. Kaufmann (eds.) Neoproterozoic Geobiology and Paleobiology. Dordrecht, the Netherlands, Springer, p. 57-90.

XIAO, S., X. YUAN, M. STEINER, AND A.H. KNOLL. 2002. Macroscopic carbonaceous compressions in a terminal Proterozoic shale; a systematic reassessment of the Miaohe biota, South China. Journal of Paleontology, 76:347-376.

YUAN, X., J. LI. AND R. CAO. 1999. A diverse metaphyte assemblage from the Neoproterozoic black shales of South China. Lethaia, 32:143-155.

ZHU, M., BABCOCK, L. E., AND M. STEINER. 2005. Fossilization modes in the Chengjiang Lagerstätte (Cambrian of China); testing the roles of organic preservation and diagenetic alteration in exceptional preservation. Palaeogeography, Palaeoclimatology, Palaeocology 220:31-46. 


\section{FIGURE CAPTIONS}

FIGURE 1- Stratigraphy of the southern subbasin of the Nama Group, Namibia. Inset: locality map. Outcrop locality 1: Vingerbreek Member at Kliphoek farm. Outcrop locality 2: Feldschuhhorn Member at Sonntagsbrunn farm. F, Feldschuhhorn Member; Ka, Kaines Member; Ma, Mara Member; Kl, Kliphoek Member; M, Mooifontein Member. After Grotzinger et al. 1995.

FIGURE $2-1$, Stratigraphic section of the Feldschuhhorn Member, Schwarzrand Subgroup; 2, Stratigraphic section of the Vingerbreek Member, Nudaus Formation, Schwarzrand Subgroup.

FIGURE 3 -: Vendotaenia antiqua Gnilosvkaya 1971 from the Feldschuhhorn Member. 1, slab, F608; 2, individual tube showing folding of tube wall, F609; 3, specimen showing sinuous bending, indicating an originally flexible tube wall, F610; 4, specimen showing dichotomous branching, F611; 5, specimen showing branching and possible differentiated termini, F612; 6 , tubes preserved as carbonaceous films, F613. Scale bar: 1, 2cm; 2, $3 \mathrm{~mm} ; 3,5 \mathrm{~mm} ; 4,5,1 \mathrm{~mm} ; 6,4 \mathrm{~mm}$.

FIGURE 4 - Vingerbreek Member fossils. 1, slab, F614; 2, specimen showing bending and overlapping of tubes as well as pitting of preserved surface, F615; 3, specimens preserved as raised ridges. Scale bar: 1, 5mm; 2, 2mm; 3, $1 \mathrm{~cm}$. 
FIGURE 5 - Histogram of tube widths measured from collected samples.

FIGURE 6 - SEM images of fossils. 1, Feldschuhhorn tube showing partial infill and impression into matrix ; 2, Vingerbreek tube showing partial infill and impression into matrix as well as surface pitting; 3, Feldschuhhorn specimen showing longitudinal striations ; 4, Close up of 3 showing pits left by evacuated pyrite crystals; 5 , Feldschuhhorn specimen showing surficial transverse lineations; 6 , Kliphoek specimen showing tube infill overhanging slab edge. Scale bars as noted.

FIGURE 7 - EDS spectra of Nama tube fossils. All spectra are normalized to the oxygen peak. Black line represents tube wall, gray line represents matrix, arrows point to significant peak differences. 1, Feldschuhhorn specimen showing elevated levels of Fe and C in tube wall. Spectra taken at $5 \mathrm{kv}$. Inset shows spectra from $0-1 \mathrm{keV} ; 2$, Feldschuhhorn specimen preserved as thin carbonaceous film, showing elevated levels of $\mathrm{C}$ with respect to matrix. Spectra taken at $5 \mathrm{kv}$. Inset shows spectra from $0-1 \mathrm{keV} ; 3$, Vingerbreek specimen showing elevated levels of Fe and $\mathrm{Mg}$ in the tube wall and elevated levels of $\mathrm{Al}$, $\mathrm{Si}$, and $\mathrm{K}$ in matrix. Spectra taken at $10 \mathrm{kv}$.

FIGURE 8 - Idealized preservation pathways for Nama tube fossils. 1: Tube on seafloor 2: Burial 3 : Buried tube decays, replaced by sediment, and preserved as raised ridge - seen in Vingerbreek member 4: Tube preserved solely as carbonaceous compression - seen in isolated locality of Feldschuhhorn, and 
globally (see text) 5: Buried tube compressed and filled in with aluminosilicates, carbonaceous material remaining. 6: Tube coated with iron-rich minerals - potential Feldschuhhorn preservation pathway 7: Tube preserved solely as mineral infill - seen in Feldschuhhorn and Vingerbreek members 8: Tube preserved solely as impression into underlying sediment - seen in both Feldschuhhorn and Vingerbreek members.

FIGURE 9 - Eastern European platform comparative material. 1, Carbonaceous Vendotaenia sp. revealed in core split; 2, Vendotaenia macerated from core material; 3, Tyrasotaenia macerated from core material. Scale bar: 1,3mm; 2, $100 \mu \mathrm{m} ; 3,400 \mu \mathrm{m}$.

FIGURE 10 - The green alga Enteromorpha, a morphological variant of Ulva, on intertidal rocks in southwestern Newfoundland. 


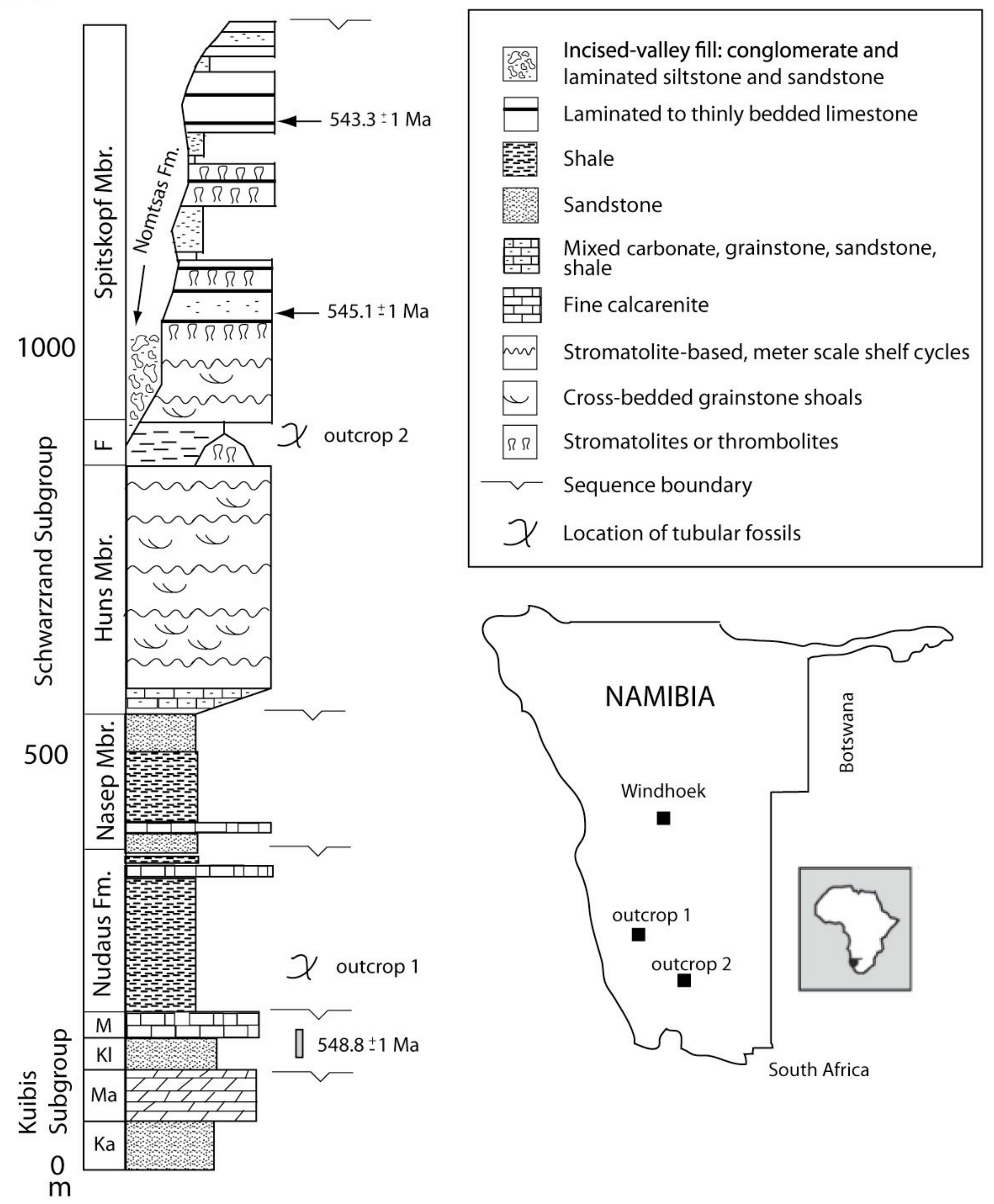


Figure 3 -
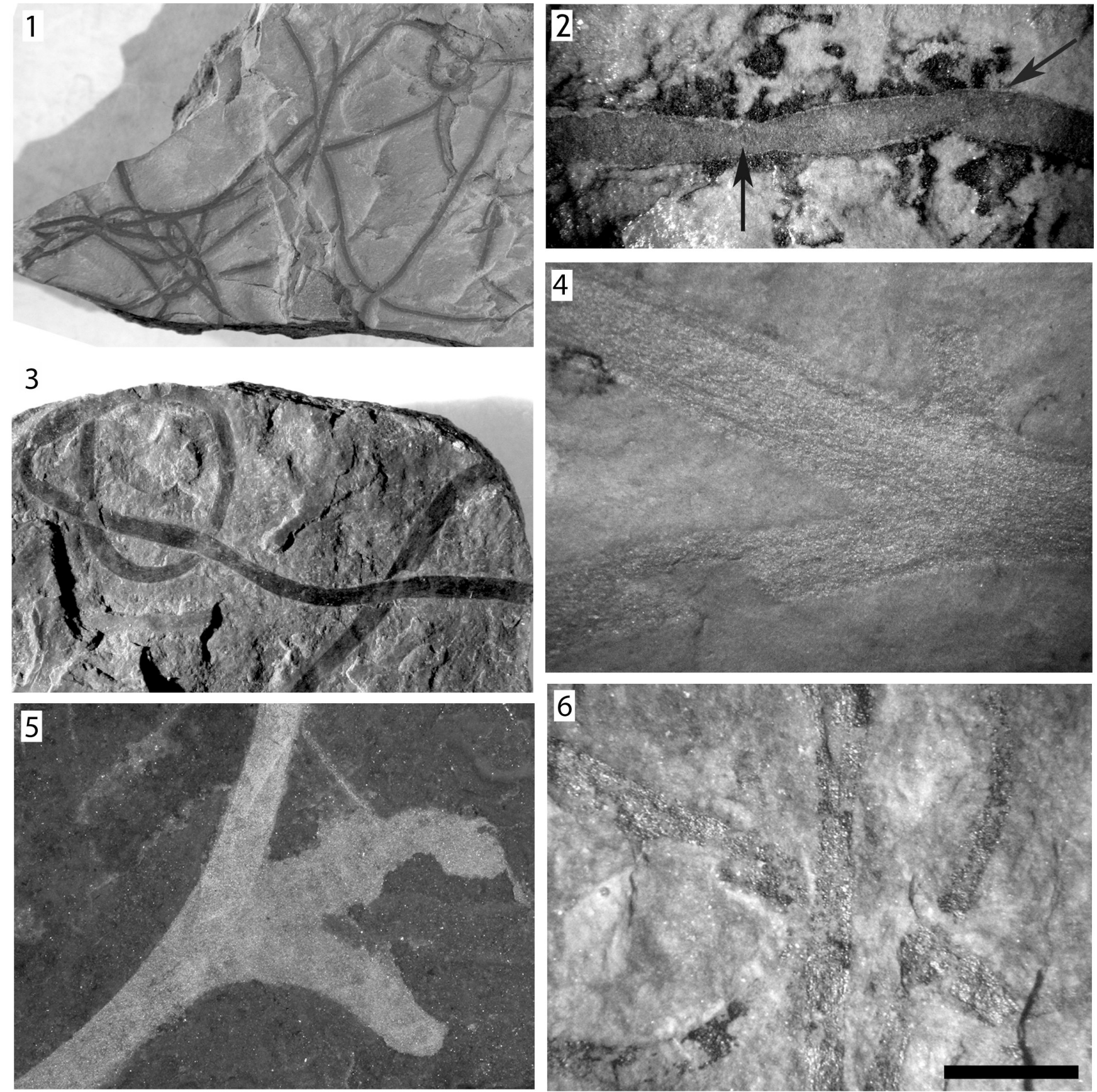

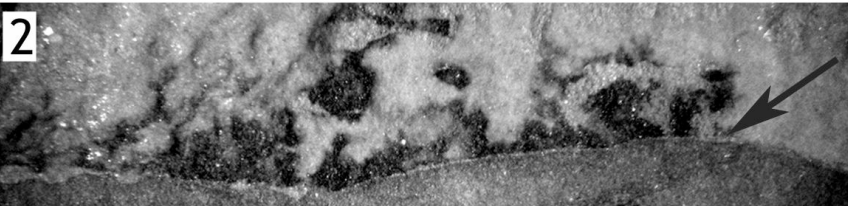
3.4
3

4

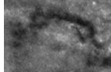

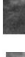
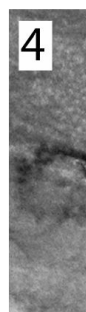


\section{FIGURE 4 -}
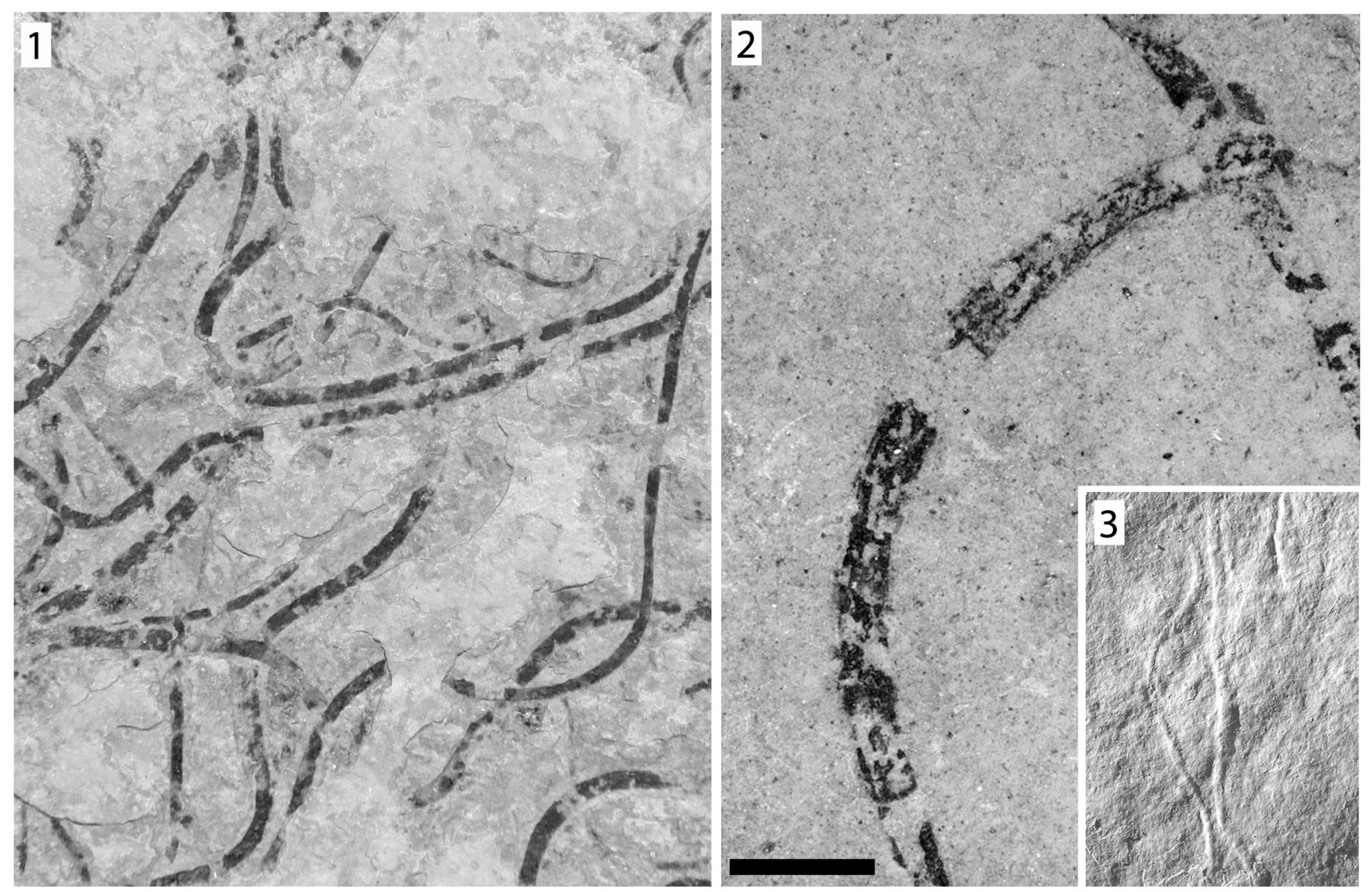
FIGURE 5 -

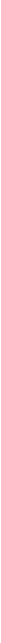




\section{FIGURE 6 -}

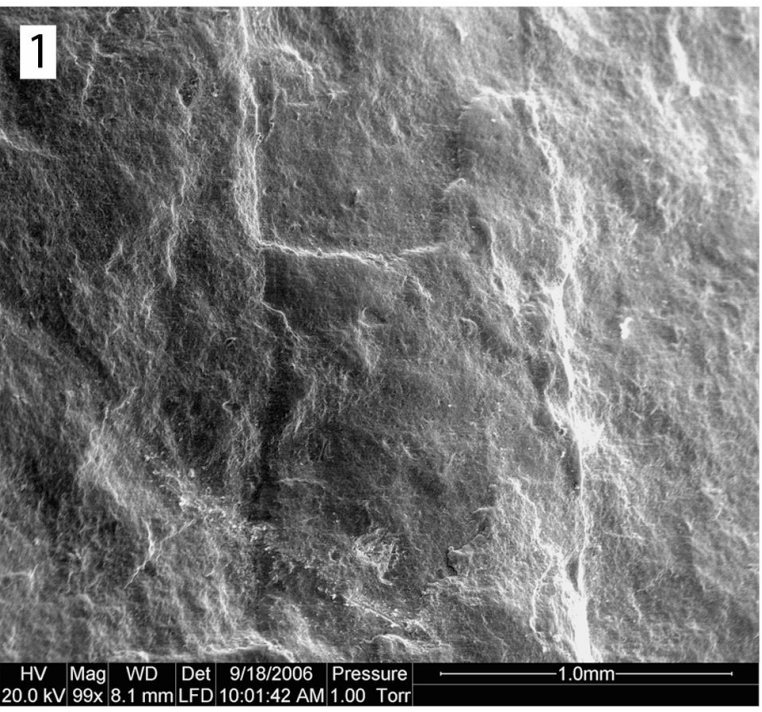

\section{2}

$1+1$

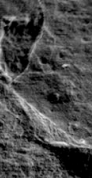

HV Mag WD Det 9/18/2006 Pressure

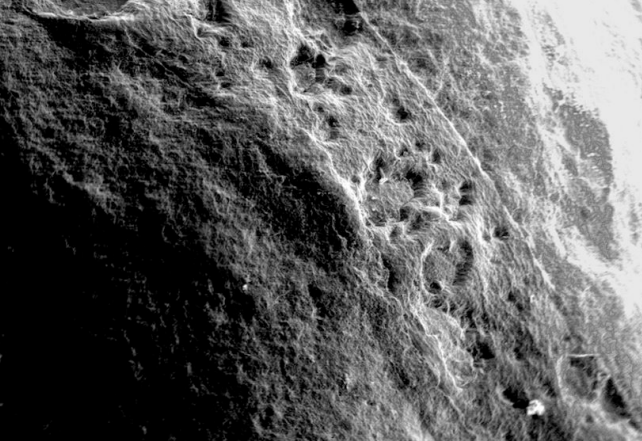

20.0 kV 63x 7.2 mmLFD 10:21:49 AM 1.00 Torr

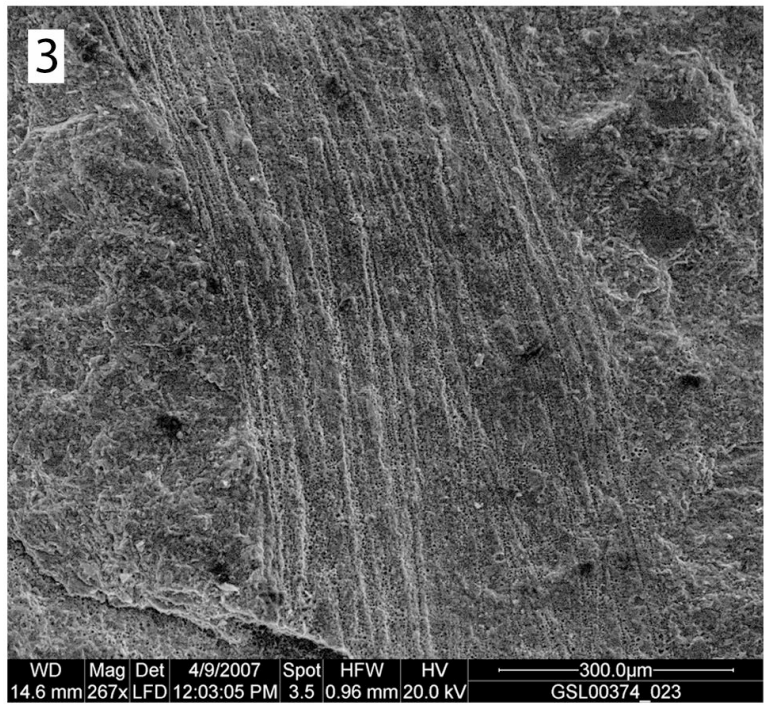

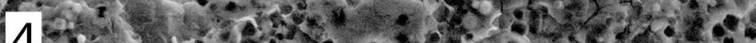

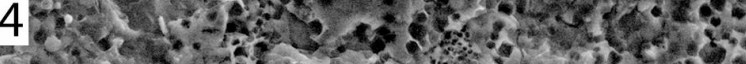

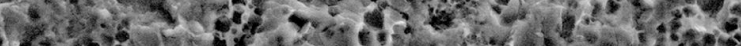

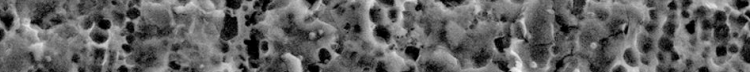

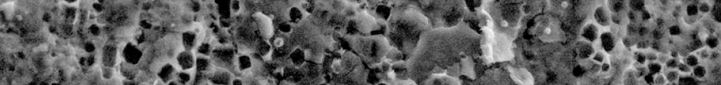

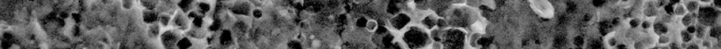

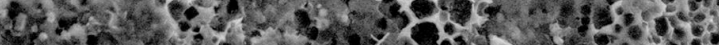

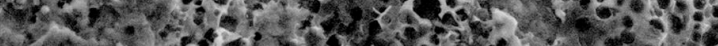

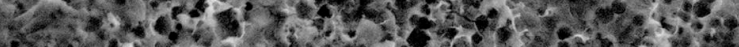

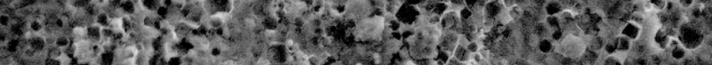

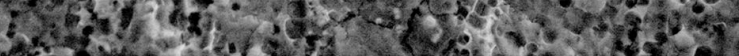

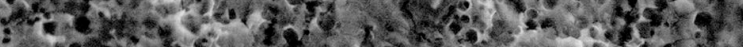

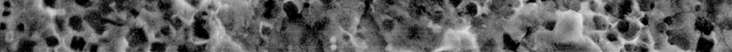

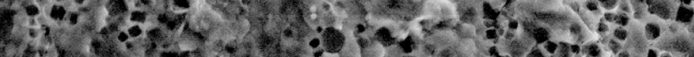

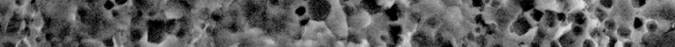

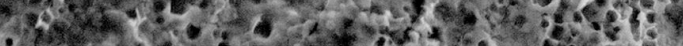

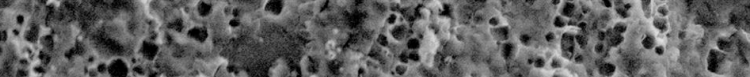

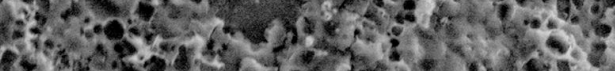

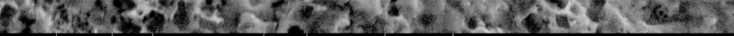

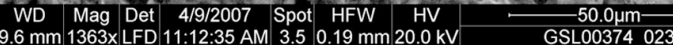
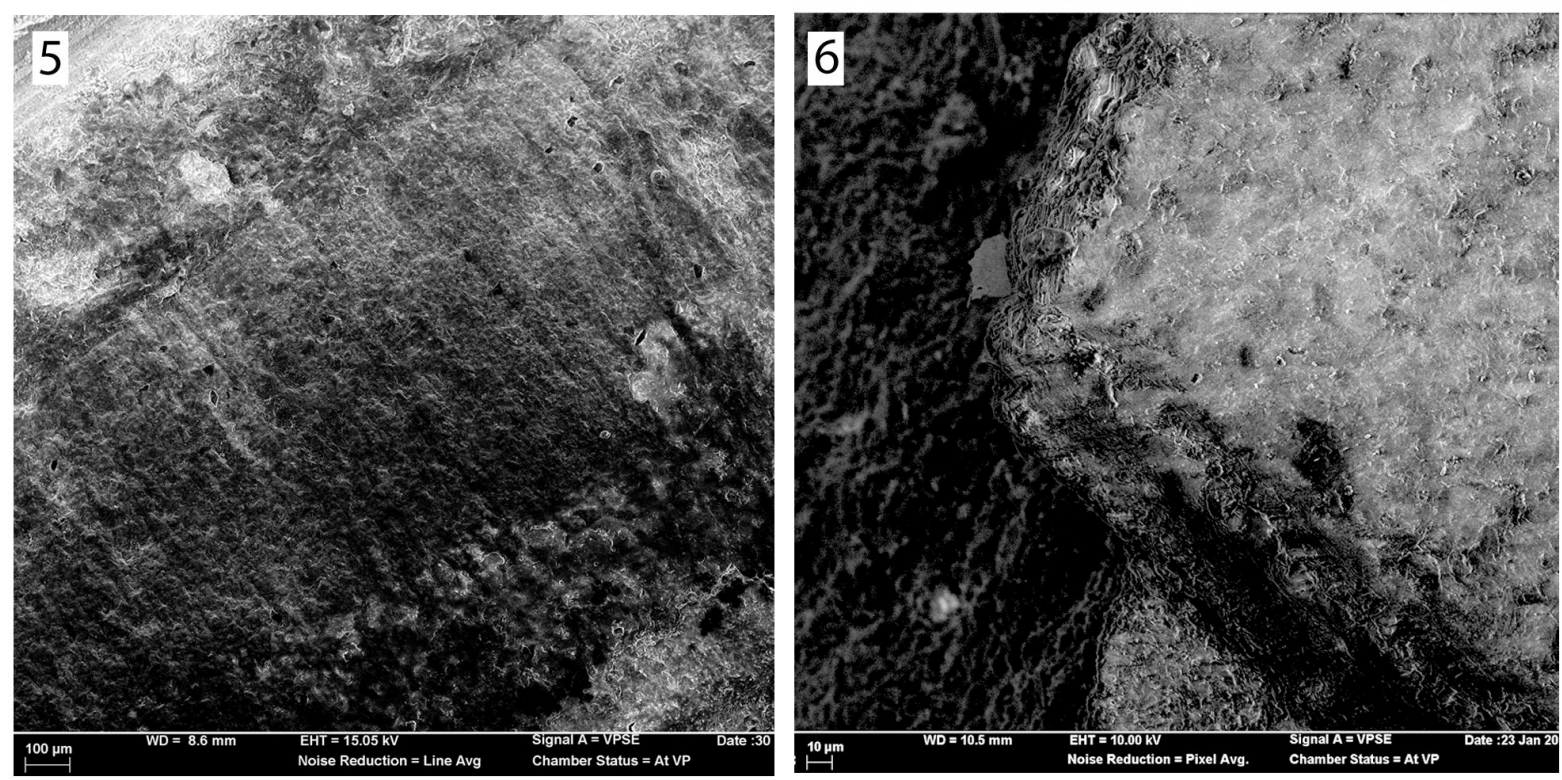
1 Feldschuhhorn Member

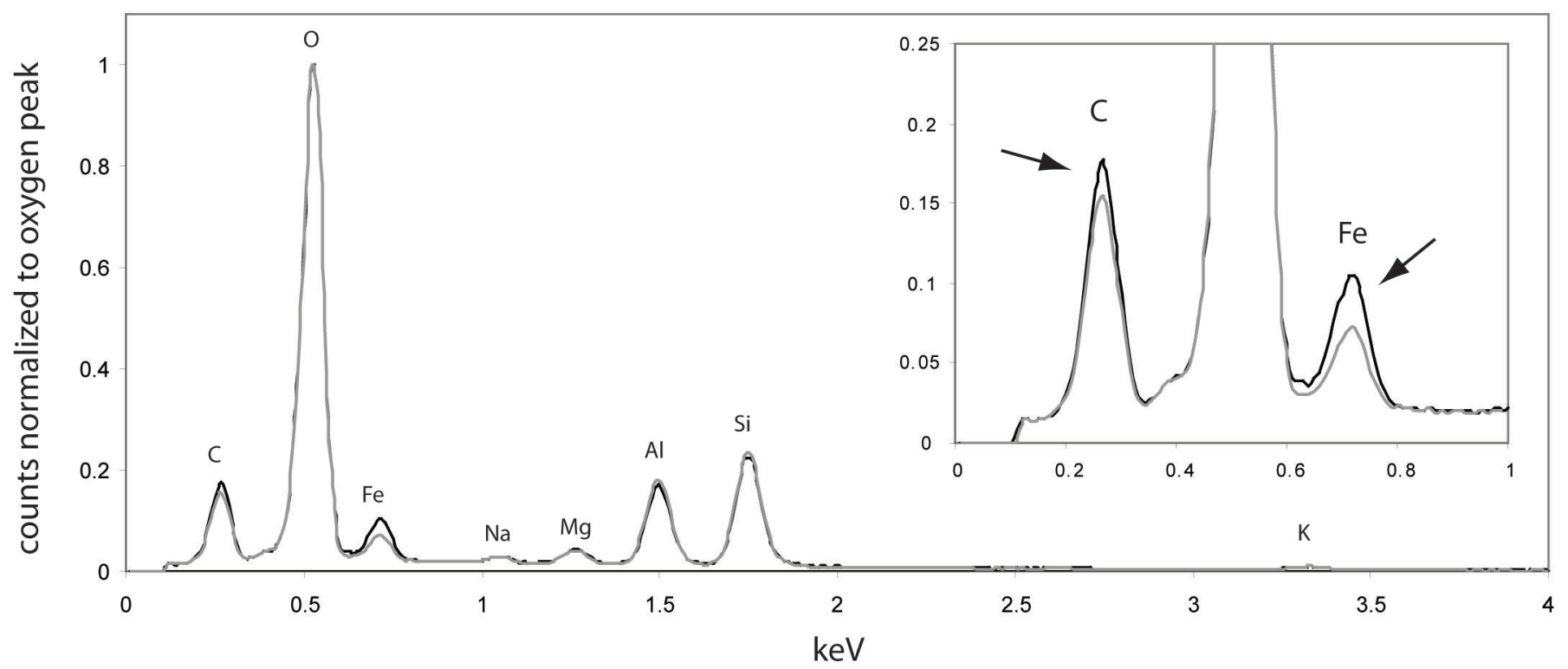

2 Feldschuhhorn Member

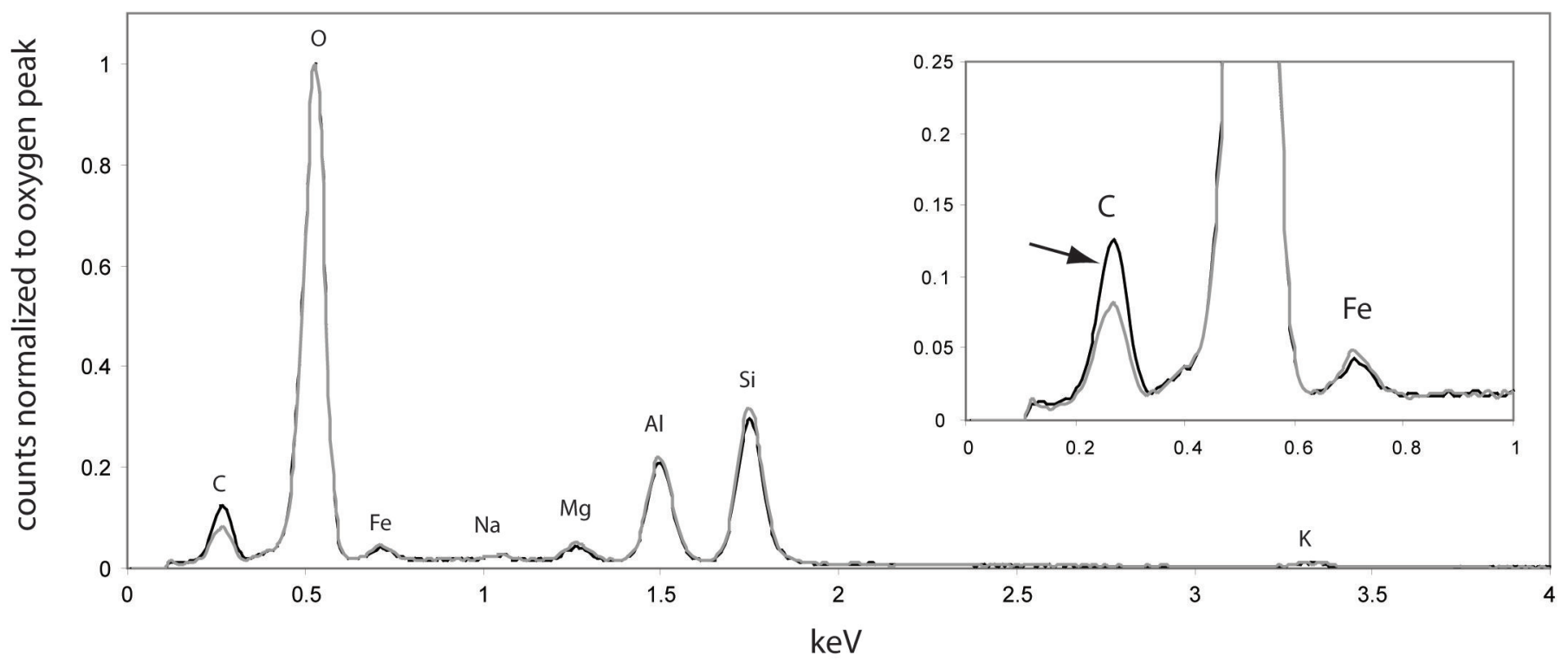

3 Vingerbreek Member

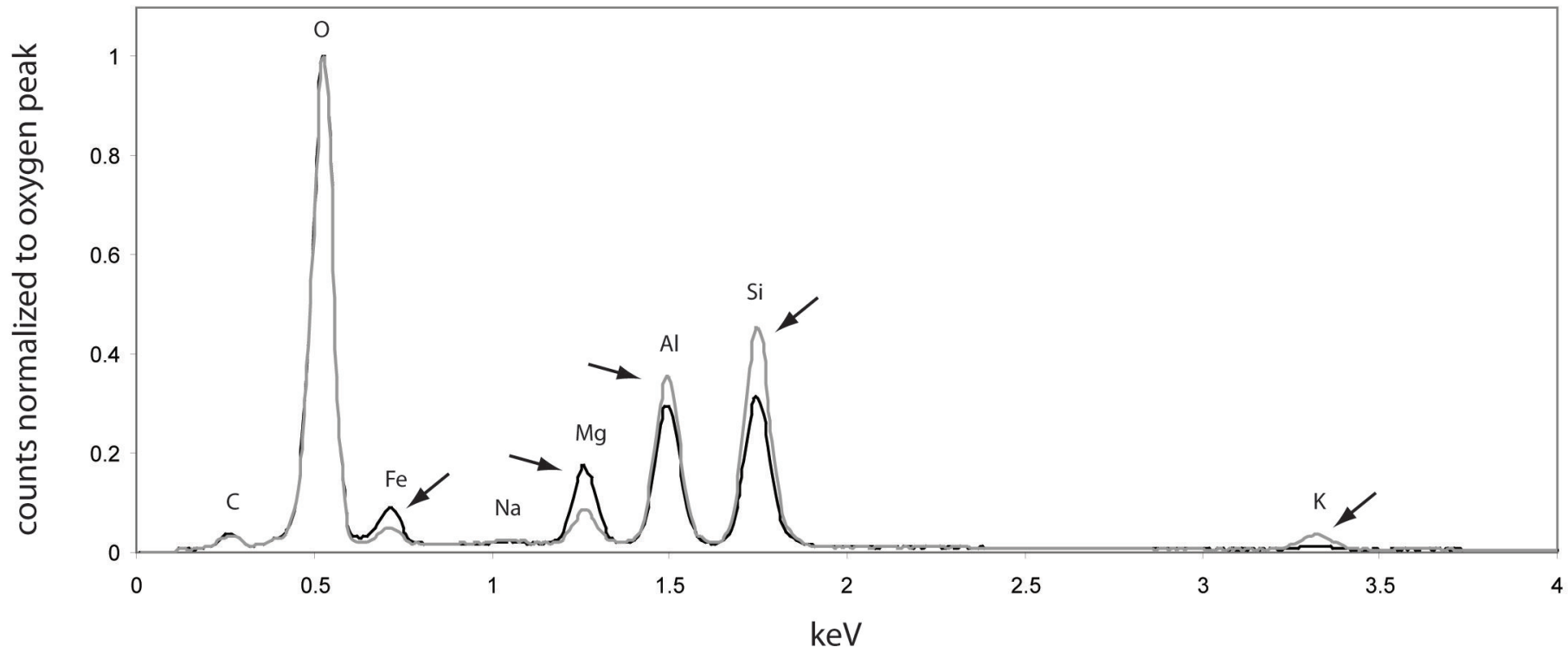


TABLE 1 - Comparison of Nama populations with previously described Ediacaran and Cambrian tubular macrofossils. ${ }^{1,2}$ Gnilovskaya, 1971,1988, 1990. ${ }^{3}$ Sokolov 1972b. ${ }^{4}$ Xiao et al. 2002.

\begin{tabular}{|c|c|c|c|c|c|c|c|}
\hline & Branching & $\begin{array}{l}\text { Longitudinal } \\
\text { striations }\end{array}$ & $\begin{array}{l}\text { Transverse } \\
\text { striations }\end{array}$ & $\begin{array}{l}\text { Twisting\& } \\
\text { Folding }\end{array}$ & $\begin{array}{l}\text { Width } \\
\text { mm }\end{array}$ & Age & Carbonaceous \\
\hline Vendotaenia $^{T}$ & Rare & $\mathrm{Y}$ & $\mathrm{N}$ & $\mathrm{Y}$ & $0.25-3.5$ & $\begin{array}{l}\text { Ediacaran - } \\
\text { ?Cambrian }\end{array}$ & $\mathrm{Y}$ \\
\hline Tyrasotaenia $^{2}$ & $\mathrm{~N}$ & $\mathrm{~N}$ & $\mathrm{~N}$ & $\mathrm{Y}$ & $0.3-0.5$ & $\begin{array}{l}\text { Latest } \\
\text { Ediacaran- basal } \\
\text { Cambrian }\end{array}$ & $\mathrm{Y}$ \\
\hline Sabellidites $^{3}$ & $\mathrm{~N}$ & $\mathrm{~N}$ & $\mathrm{Y}$ & $\mathrm{Y}$ & $0.5-3$ & $\begin{array}{l}\text { Ediacaran - } \\
\text { Cambrian }\end{array}$ & $\mathrm{Y}$ \\
\hline $\begin{array}{l}\text { Sinocylindrica } \\
\text { yunnanensis }^{4}\end{array}$ & $\mathrm{~N}$ & $\mathrm{~N}$ & $\mathrm{~N}$ & $\mathrm{Y}$ & $0.2-0.35$ & $\begin{array}{l}\text { Ediacaran - } \\
\text { Cambrian }\end{array}$ & $\mathrm{Y}$ \\
\hline $\begin{array}{l}\text { Vingersbreek } \\
\text { fossils }\end{array}$ & $\mathrm{N}$ & $\mathrm{N}$ & Rare & $\mathrm{N}$ & $0.6-2.0$ & Ediacaran & $\mathrm{N}$ \\
\hline $\begin{array}{l}\text { Feldschuhhorn } \\
\text { fossils }\end{array}$ & Rare & $\mathrm{Y}$ & Rare & $\mathrm{Y}$ & $0.6-2.1$ & Ediacaran & Rare \\
\hline
\end{tabular}


FIG 8 -

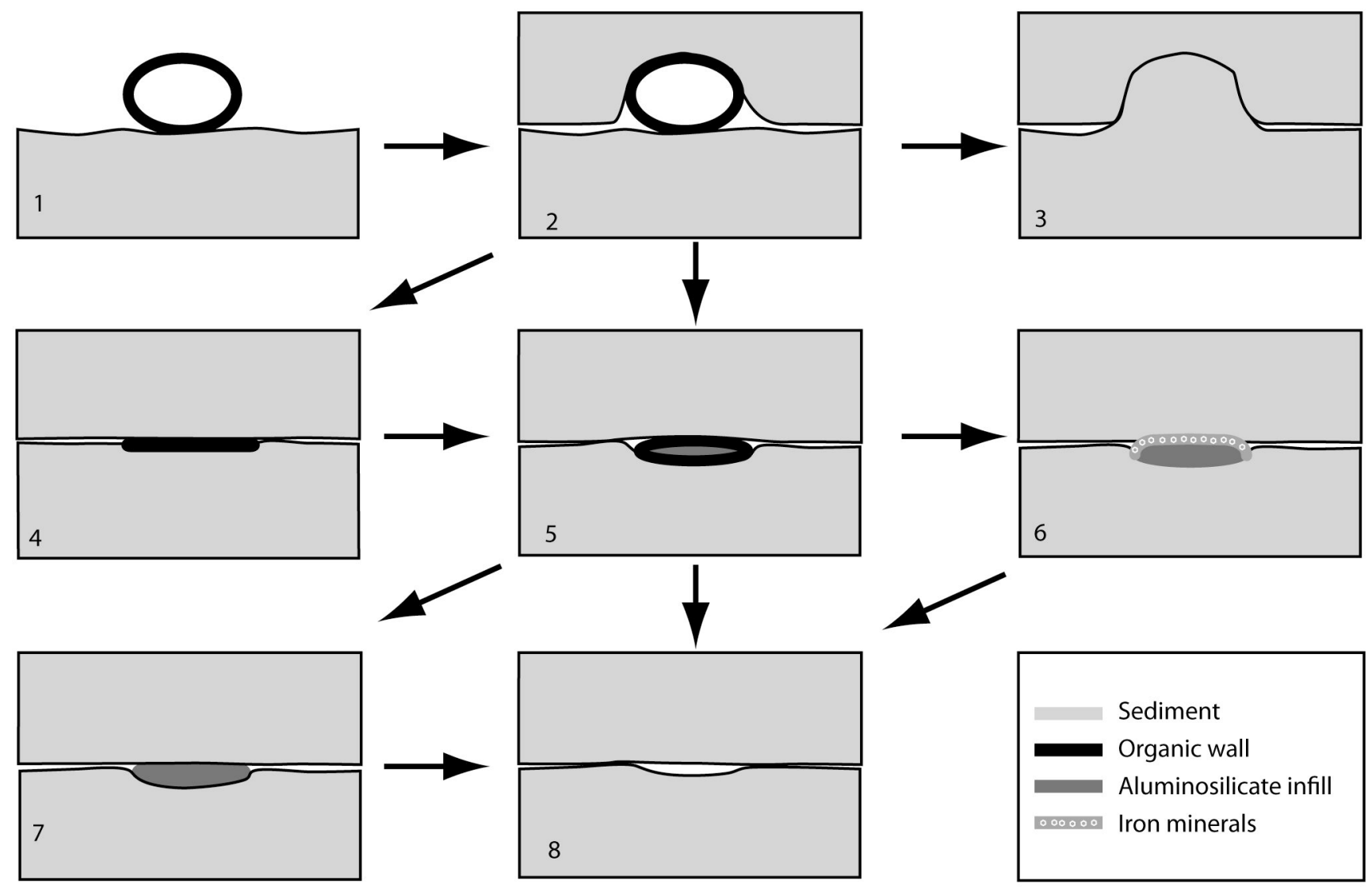




\section{FIG 10-}

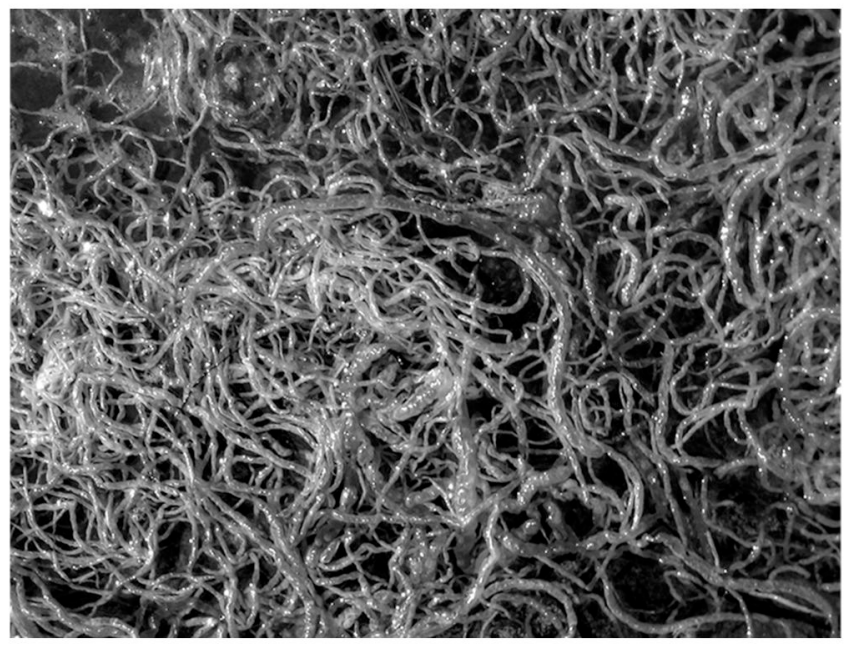

